\title{
Price Fixing Among Elite Colleges and Universities
}

\author{
Richard Morrison $\dagger$
}

On May 22, 1991, the Department of Justice filed a complaint against the eight Ivy League schools and the Massachusetts Institute of Technology alleging that the schools colluded to raise tuition rates and reduce financial aid awards for certain admitted applicants. ${ }^{1}$ On the same day, the eight Ivy League schools, but not M.I.T., settled the Department of Justice complaint by signing a consent decree. ${ }^{2}$ Among other things, the decree prevents the schools from jointly fixing tuition or financial aid and from exchanging financial aid information on admitted applicants. ${ }^{3}$ The Department of Justice's investigation of financial aid and tuition practices, which began in August 1989, eventually covered fiftyseven colleges and universities. ${ }^{4}$ Among the colleges investigated were twenty-three private colleges called the Overlap Group. ${ }^{5}$ These schools met each spring just before final admission decisions to share information on financial aid and to jointly set tuitions and

$\dagger$ B.A., B.S., 1989, University of Kansas; J.D. and M.A. Candidate 1993, The University of Chicago.

1 United States v Brown, Civil Action No 91-CV-3274, Complaint (E D Pa, May 22, 1991). Section 4 of the Sherman Antitrust Act authorizes the U.S. Attorney General to seek injunctions against violations of the antitrust laws. 15 USC $\S 4$ (1988).

2 Brown, Civil Action No 91-CV-3274, Stipulation; Anthony DePalma, Amid Inquiry, Ivy League to Stop Sharing Aid Data, NY Times A1 (May 23, 1991); Department of Justice, Consent Decree Settles Charge of Conspiracy to Restrain Price Competition on Financial Aid Against Major Universities (May 22, 1991).

${ }^{3}$ Brown, Stipulation at 4-5 (cited in note 2).

1 Goldie Blumenstyk and Christopher Myers, U.S. Probes Tuition and Student Aid on 20 Private Campuses, 35 Chron Higher Ed A1, A26 (Aug 16, 1989); Christopher B. Daly, Like Fall Applicants, Colleges Await Fate, Wash Post A1 (Apr 7, 1990). For a list of the colleges and universities under investigation, see Dennis Kelly, Colleges Stop Swapping Aid Data; Schools Under Investigation, USA Today 6D (Mar 14, 1991). In mid-1991, the investigation was widened to include admissions policies at fifteen schools. Michael Weisskopf and Tom Kenworthy, New Data Sought from Colleges, Wash Post A17 (Jul 24, 1991).

The Department of Justice sent civil investigative demands, which enable the Antitrust Division of the Department of Justice to examine business records before a formal civil suit is filed. Daly, Wash Post at A1; E. Thomas Sullivan and Herbert Hovenkamp, Antitrust Law, Policy and Procedure: Cases, Materials, Problems 73-74 (Michie, 2d ed 1989).

The Overlap Group includes the eight Ivy League schools that signed the May 22, 1991 consent decree. 
financial aid awards. ${ }^{6}$ In addition to the Department of Justice investigation, twelve schools also face a private lawsuit filed by a Wesleyan University student."

The private suit and the Department of Justice complaint allege that the schools have violated $\S 1$ of the Sherman Antitrust Act, which provides, in part, that: "Every contract, combination in the form of trust or otherwise, or conspiracy, in restraint of trade or commerce among the several States, or with foreign nations, is declared to be illegal." B Because courts have recognized that all contracts restrain trade in some way, ${ }^{9}$ they have developed mechanisms for distinguishing between those restraints that are legal and those that are illegal. Specifically, courts apply one of two tests: the per se rule or the rule of reason. Some categories of restraints are per se illegal because their "nature and necessary effect are so plainly anticompetitive that no elaborate study of the industry is needed to establish their illegality."10 Horizontal price fixing, a conspiracy by various producers of the same product to fix the price of the product, is one example of an agreement that is usually considered a per se violation of $\S 1$ of the Sherman Act. ${ }^{11}$ The reasonableness of the fixed price is irrelevant to the courts' determination of illegality. ${ }^{12}$

In contrast to the limited inquiry undertaken in cases of per se violations, trial of a "rule of reason" antitrust case requires weigh-

- See Susan Chira, 23 Colleges Won't Pool Fiscal Data, NY Times B7 (Mar 13, 1991). In response to the federal antitrust investigation, the Overlap Group decided not to meet in 1991. Id.

${ }^{7}$ Kingsepp $v$ Wesleyan University, 763 F Supp 22, 23 (S D NY 1991). The twelve schools involved in this suit are Yale, Wesleyan University, Princeton, Dartmouth, Stanford, Brown, Amherst, Williams, the University of Pennsylvania, Columbia, Cornell, and Harvard. Id at 22. For more information see Scott Jaschik, Suit Charges 12 Private Colleges With Conspiracy, 36 Chron Higher Ed 1, A30 (Sep 27, 1989). Antitrust lawsuits by private parties are authorized by $\S 4$ of the Clayton Act, which also permits a court to award treble damages in such cases. 15 USC § 15 (1988).

815 USC $\S 1$.

- See NCAA v Board of Regents of University of Oklahoma, 468 US 85, 98 (1984); Standard Oil Co. v United States, 221 US 1, 59-60 (1911).

10 National Soc. of Professional Engineers v United States, 435 US 679, 692 (1978) ("Professional Engineers"); see also Broadcast Music, Inc. v Columbia Broadcasting System, Inc., 441 US 1, 7-8 (1979).

${ }^{11}$ See United States v Socony-Vacuum Oil Co., 310 US 150, 218 (1940) ("[F]or over forty years this Court has consistently and without deviation adhered to the principle that price-fixing agreements are unlawful per se under the Sherman Act and that no showing of so-called competitive abuses or evils which those agreements were designed to eliminate or alleviate may be interposed as a defense."); United States v Trenton Potteries, 273 US 392, 395-402 (1927)(combination to fix and maintain uniform prices for the sale of sanitary pottery illegal).

12 Trenton Potteries, 273 US at 395-402. 
ing "all of the circumstances of a case in deciding whether a restrictive practice should be prohibited as imposing an unreasonable restraint on competition." ${ }^{13}$ A court following the rule of reason takes into account many factors to determine the effect on competition. ${ }^{14}$

Both rules, however, share a common goal: "to form a judgment about the competitive significance of the restraint."15 The difference between them is that the per se rule presumes illegality based upon the judiciary's experience that the type of restraint in question is anticompetitive, while the rule of reason involves an actual market analysis. ${ }^{16}$ However, there is no bright line rule separating the two forms of analysis. ${ }^{17}$ Indeed, "[p]er se rules may require considerable inquiry into market conditions before the evidence justifies a presumption of anticompetitive conduct."18

This Comment argues that the alleged conduct of the schools under investigation by the Department of Justice violated $\S 1$ of the Sherman Antitrust Act. The investigated colleges jointly set financial aid awards and exchanged financial information on applicants. ${ }^{19}$ When schools cooperate to set tuition and financial aid awards, they are able to assure that students receive a uniform financial aid package at each participating school to which they apply, and thereby avoid bidding against each other for students. ${ }^{20}$

This Comment argues that this cooperation in fixing financial aid awards is illegal. The schools' conduct is exactly analogous to the conduct of ordinary price-fixing cartels, and the harm to con-

${ }^{13}$ Continental T.V., Inc. v GTE Sylvania, Inc., 433 US 36, 49 (1977).

14 NCAA, 468 US at 103, citing Professional Engineers, 435 US at 690.

${ }^{16}$ Professional Engineers, 435 US at 692.

${ }^{16}$ See NCAA, 468 US at 104.

${ }^{27}$ Id at $104 \mathrm{n} 26$.

18 Id.

19 A New York Times editorial by Paul E. Gray, chairman and former president of the Massachusetts Institute of Technology, claims:

Many other private institutions have similar aid practices [to Massachusetts Institute of Technology's need-based financial aid policy]. Consequently, applicants to more than one of these schools can expect similar [determinations of] parental contributions and levels of need-based aid. Indeed, to insure consistency, financial aid officers from many private universities, including M.I.T., have in the past met to discuss their methods and to compare awards. Their openly declared aim has been to see that students receive the aid they need, allowing them to select a school that offers the most suitable education, not the most money.

Paul E. Gray, Measure Need, Not Money, NY Times A15 (Jul 22, 1991).

${ }^{20}$ See Edward B. Fiske, Colleges and Costs, NY Times (Natl ed Aug 11, 1989). Said Amy Nychis, financial aid director at Wellesley, "It should not cost a family any more money to go to Harvard or to a cheaper institution." Kenneth J. Cooper, 23 Colleges to Share Data on Applicants' Finances, Wash Post A12 (Mar 27, 1990). 
sumers (students) is as compelling a justification for enjoining the schools' conduct. Even under the more lenient "rule of reason" standard, ${ }^{21}$ the schools cannot successfully argue that because their arrangement should be exempt from antitrust regulation it provides public benefits that would not otherwise be supplied by the free market. ${ }^{22}$

This Comment is divided into four parts. Section I examines the effects of cartel pricing by colleges and universities. Section II discusses the legal implications of the behavior of colleges and universities as if they were ordinary businesses. Section III examines first, the present treatment of social benefits under antitrust law, and second, whether the education cartel provides social benefits. In Section IV, this Comment concludes that although the cartel may provide some social benefits that the competitive market cannot, these benefits do not justify an antitrust exemption for colleges participating in the education cartel..$^{23}$

\section{An Analysis of Cartel Pricing on the Market FOR Higher EDUCATION}

Colleges and universities collect financial aid information both directly from students and through nationwide agencies. In addition, from the 1950 s to 1990 , some of the schools exchanged financial aid data at the annual meetings. ${ }^{24}$ At these meetings, the schools may also have fixed base tuition rates and coordinated the amount of financial aid awarded to each student so that the student received the same financial aid package at each school. ${ }^{25}$ This attempt to equalize net tuition rates resembles the classic model of cartel practices.

22 See text accompanying notes 13-14.

${ }^{22}$ See Douglas R. Richmond, Private Colleges and Tuition Price-Fixing: An Antitrust Primer, 17 J Coll \& Univ L 271, 296 (1991) (universities will probably be found liable under either the per se rule or rule of reason).

${ }^{23}$ This Comment does not examine whether colluding schools are protected by the First Amendment. See J. Peter Byrne, Academic Freedom: A "Special Concern of the First Amendment," 99 Yale L J 251, 333 n 325 (1989) (Department of Justice price-fixing investigation "potentially in violation of constitutional academic freedom"). But see University of Pennsylvania v Equal Employment Opportunity Commission, 110 S Ct 577, 585-88 (1990) (First Amendment does not protect university from having to disclose tenure review documents to the Equal Employment Opportunity Commission in a hiring discrimination case).

${ }^{24}$ Chira, NY Times B7 (cited in note 6).

${ }^{25}$ See text accompanying notes 6-8. 
A. Anticompetitive Effects: Cartelization, Market Power, and Price Discrimination

1. Cartel behavior.

A cartel is a group of competitors that jointly agree to raise their prices (and thus their revenues) to a higher level than that which would prevail if the parties sold the product in competition with one another. ${ }^{26}$ The cartel attempts to behave like a monopolist, increasing price and reducing output in order to capture profits. ${ }^{27}$ The decrease in output and increase in price results in a loss to consumers and a gain to producers. Moreover, in a cartel situation, the losses to consumers exceed the gains to the cartel, producing a net loss in welfare, ${ }^{28}$ because a cartel reduces output even when the consumer gain from the output would outweigh the cost of the output.29

According to the economic model of cartel behavior, colluding schools would charge higher net tuition (base tuition minus financial aid) than the schools that compete with each other. The schools could raise net tuition either by increasing their base tuition rates or by reducing some financial aid awards..$^{30}$

2. Market power.

A cartel must possess market power-the ability to raise prices-in order to be successful. Elite schools such as the twentythree participants in the Overlap Group probably possess a high degree of market power because the reputation commanded by these schools carves out a distinct market for their educational services. ${ }^{31}$ Additional evidence of market power stems from the schools' ability to use financial aid to effectively price discriminate among students. ${ }^{32}$

${ }^{26}$ Edgar K. Browning and Jacqueline M. Browning, Microeconomic Theory and Applications 374 (Little, Brown, 2d ed 1986); Herbert Hovenkamp, Economics and Federal Antitrust Law 83 (West, 1985).

${ }^{27}$ See Hal R. Varian, Intermediate Microeconomics 429 (Norton, 1987); Roger D. Blair and David L. Kaserman, Antitrust Economics 136 (Richard D. Irwin, 1985).

${ }^{28}$ See Blair and Kaserman, Antitrust Economics at 35-37 (cited in note 27).

20 Id at 37 (discussing monopolists).

30 While the simple cartel model suggests that higher net tuition could ordinarily reduce output-the number of students educated each year-the complete output effects for college education are complicated and are discussed in Section I.D.2.

"11 David A. Garvin, The Economics of University Behavior 10 (Academic Press, 1980).

32 Price discrimination by a firm is normally an indicator of market power. Hovenkamp, Economics and Federal Antitrust Law at 103 (cited in note 26). 
Horizontal price fixing is illegal even when there is no proof that the cartel possesses market power. ${ }^{33}$ However, evidence of market power is often relevant in antitrust cases such as that being developed against the education cartel ${ }^{34}$ If the plaintiff, either the Department of Justice or a private party, cannot prove that the schools explicitly agreed to fix tuition, courts may use evidence of market power in addition to evidence demonstrating an exchange of price information to infer collusion. ${ }^{35}$

\section{Price discrimination.}

The process by which schools award financial aid appears on its face to be a classic example of the economic model of price discrimination. Price discriminators charge different prices to different consumers for the same item based on the consumers' willingness to pay. ${ }^{36} \mathrm{~A}$ perfect price discriminator will charge each consumer the maximum price the consumer is willing to pay-the consumer's "reservation price." By charging the full amount that consumers are willing to pay, a price discriminator captures wealth that would, in a competitive market, remain in consumers' pockets. ${ }^{37}$ Schools price discriminate by charging some students full tuition and giving other students income-calibrated financial aid to offset the base tuition. Although price discrimination by sellers of commodities is illegal under the Robinson-Patman Act, schools sell services and are therefore exempt from that statute. ${ }^{38}$

${ }^{33}$ NCAA, 468 US at 109 ("As a matter of law, the absence of proof of market power does not justify a naked restriction on price or output. To the contrary, when there is an agreement not to compete in terms of price or output, 'no elaborate industry analysis is required to demonstrate the anticompetitive character of such an agreement.' ") (citation omitted). See also Hovenkamp, Economics and Federal Antitrust Law at 56 (cited in note 26).

34 For further discussion, see Richmond, $17 \mathrm{~J}$ Coll \& Univ L at 299 (cited in note 22).

${ }^{35}$ United States v Container Corporation of America, 393 US 333, 336-37 (1969) (Court used rudimentary market analysis, determining that defendants possessed $90 \%$ of market, before deciding that an informal information exchange was illegal).

${ }^{38}$ See Hovenkamp, Economics and Federal Antitrust Law at 338 (cited in note 26); Blair and Kaserman, Antitrust Economics at 259 (cited in note 27). Differences in price that reflect differences in the cost of providing goods to consumers (due to transportation costs, local regulation or other regional variables) are not illegal. Hovenkamp, Economics and Federal Antitrust Law at 338 (cited in note 26). See also the Robinson-Patman Act, 15 USC § 13(a) (1990) (legal definition of price discrimination).

${ }^{37}$ See Varian, Intermediate Microeconomics at 431 (cited in note 27).

${ }^{38}$ See 15 USC \$13(a) (outlawing price discrimination "between different purchasers of commodities of like grade and quality" where the effect reduces competition and the price differential is not a "due allowance for differences in cost") (emphasis added). 
Colleges and universities are uniquely positioned to price discriminate among students because the barriers that may prevent businesses from practicing perfect price discrimination do not restrict them. First, ordinary firms are usually unable to ascertain the maximum amount each consumer is willing to pay for a product. $^{39}$ However, the information schools obtain from financial aid forms, especially students' income and assets, greatly aid them in determining each student's reservation price. Students who misrepresent their income on financial aid forms face severe penalties, ${ }^{40}$ thus insuring that the schools have reliable information on which to base their estimates of reservation prices.

Second, schools do not face the problem of arbitrage. Businesses that price discriminate often find that low-paying customers will sell their purchases to high-paying consumers, luring the highpaying customers away from the original supplier. ${ }^{41}$ Financial aid recipients, on the other hand, cannot sell their university places to those students who do not receive financial aid.

Third, elite private colleges probably have more market power when they operate as a cartel, and thus are able to charge some consumers higher prices without driving them away. ${ }^{42}$ The more market power a firm or cartel has, the greater its ability to charge differential prices. $^{43}$ A price discriminating cartel makes more profit than either an individual price discriminator or a cartel that is unable to price discriminate. Thus an individual school, lacking the cartel's combined market power, would not be able to price discriminate as effectively. Even though individual schools may legally engage in price discrimination, ${ }^{44}$ the added power of the cartel may increase the wealth transfer away from students and to the participating colleges and universities.

39 Robert S. Pindyck and Daniel L. Rubinfeld, Microeconomics 377 (Macmillan, 1989).

10 For example, the College Entrance Examination Board, Financial Aid Form (199192), provides:

You must provide correct information. Deliberate misrepresentation of information on financial aid application forms is a violation of federal and state law and may be considered a criminal offense which could result in indictment under the U.S. Criminal Code and/or disciplinary action by, or expulsion from, the University. Funds obtained on the basis of false information must be repaid immediately.

4 See Blair and Kaserman, Antitrust Economics at 262-63 (cited in note 27).

12 A firm or cartel cannot price discriminate unless it has the power to influence the price consumers pay. Otherwise customers who are asked to pay the discriminatorily high price will find another producer or buy a less expensive product. See Hovenkamp, Economics and Federal Antitrust Law at 103 (cited in note 26).

${ }^{43}$ See id.

"See text accompanying note 38 . 
B. Schools' Motives for Awarding Financial Aid

There are four primary reasons why schools give financial aid to their students. First, some financial aid may be the result of revenue-maximizing price discrimination. Price discriminating schools may be calibrating their net tuition to a student's reservation price by giving financial aid to students who are poorer and thus less willing to pay. To most effectively price discriminate, schools must charge, as a base tuition, the highest price that any student is willing to pay. However, a price discriminating cartel would not want to drive away poorer students by setting a uniformly high monopoly price. By awarding financial aid, the schools may charge a price that the student will pay while still receiving a higher-than-competitive profit.

Second, a school may offer a student financial aid because having that student in the class will improve the quality of the school, specifically, its reputation or the diversity of its student body. Scholarship aid may be offered to students who possess desirable characteristics: intelligence, ethnicity, economic disadvantage, or geographic diversity, among others.

Third, a school may offer financial aid to maintain or secure charitable donations from donors who may have preferences about the school's financial aid policies. This type of financial aid is not a benefit of cartel power because it would exist in a competitive market.

Fourth, the school may offer financial aid out of sheer altruism to further the welfare of the student or society. This motive is different from revenue-based motives for giving financial aid such as price discrimination, attracting desirable students, or attracting gifts to the university. This purely altruistic financial aid probably is partly financed by the higher-than-competitive net tuition paid by other students; it is a cross-subsidy from one group of students to another. ${ }^{45}$

\section{Use of Cartel Profits}

One cannot clearly determine the motive behind any individual financial aid award. An individual student may receive financial aid because the school is motivated by price discrimination, by quality improvement through diversity, by pure charity, or, most likely, a mixture of the three. Schools do not necessarily price dis- 
criminate at the prices that a profit-maximizer would choose; other motives (such as altruism or quality improvement through diversity) may lead schools to deviate from a complete profit-maximization strategy. But in any event, even a purely altruistic cartel could, and probably does, charge a higher net tuition to some students by using its cartel power. ${ }^{46}$

The cartel profits made on excessively high tuition charged to some students may provide a cross-subsidy to other students in the form of altruistic financial aid. However, the money might also be spent on teacher salaries, football stadiums, lawn care, or wasteful expenditures. Thus, the fact that universities spend all their revenues ${ }^{47}$ does not show that they do not exercise cartel power. ${ }^{48}$

It is difficult to determine whether financial aid represents true cross-subsidization or a straight price discrimination scheme. Since revenues from tuition and endowments are lumped together, it would be impossible to match sources of funds to spending categories. One thing is certain, however, cartel profits are distributed to some students only at the expense of others.

\section{Effects of Eliminating Cartel Power}

1. Effect on revenues, costs, and financial aid.

Forcing schools to make independent decisions would almost certainly reduce artificially high net tuition charged to some students. Although it is difficult to determine whether the tuition

\footnotetext{
16 To be sure, an altrusitic cartel might consciously restrict its use of cartel power (and the accompanying ability to price discriminate), and charge each student the net tuition that would exist in a competitive environment. But, as illustrated in Section IV.A., this is unlikely.

47 For example, Dennis O'Brien, President of the University of Rochester, complained: "With all the troubles of trying to run universities, upgrading research facilities, bringing in minority students, and deferred maintenance, and have someone come and say we're pricegouging and colluding-it really frosts me." Catherine Foster, Probe Studies Price-Fixing Charges, Christian Sci Mon 7 (Sep 22, 1989).

${ }^{18}$ Even if the base tuition rate the school charges does not cover the average cost of educating a student, the relationship between base tuition and cost does not prove that the schools are behaving competitively. First, many schools include financial aid awards in "cost." However, not all financial aid is really economic cost. Some financial aid is merely compensation for higher-than-competitive base tuition. Other financial aid is given purely out of altruism, and is not economic cost at all. Second, there is no reason to think that the other sources of revenue (charitable contributions, government subsidies, and athletic revenues) that make up the remaining gap between base tuition and economic cost will dry up if colleges were not allowed to collude. Finally, the existence of the cartel may enable costs to increase unnecessarily, because in the absence of competition, cartel participants feel no pressures to cut or control costs. See Harvey Leibenstein, Allocative Efficiency $v$. " $X$-inefficiency", 56 Am Econ Rev 392 (1966).
} 
charged by the cartel is above cost and thus whether it is possible for the universities to cut prices, elimination of a cartel typically leads to lower prices due to competitive pressures on cost and price. ${ }^{49}$

Eliminating cartel power would have two positive effects and one negative effect on financial aid policies. The first benefit would be that the need for some financial aid would be eliminated because the base tuition rate would probably fall, making education more affordable. At a minimum, competitiveness will decrease "phantom financial aid"- that portion of aid that offsets the artificially high monopoly base tuition rate, but that does not reduce the net tuition below the competitive price. ${ }^{50}$ Second, schools will likely focus their financial aid efforts on students whose enrollment improves educational quality. ${ }^{51}$ In a regime in which schools must compete to enroll high-quality students, those students would be able to extract more favorable awards.

An admittedly negative effect of eliminating cartel power would be that the resulting decrease in cartel profits would probably reduce some truly charitable financial aid awards. Schools with lower revenues are less likely to make expenditures on unprofitable items such as altruistic financial aid. However, two factors reduce the potential magnitude of this undesirable reduction. First, the amount of financial aid awards that are motivated solely by altruism may be small compared to financial aid designed to entice quality students or financial aid designed to offset artificially high base tuition. Second, altruistic financial aid awards will remain to the extent that they are funded by alumni and government contributions.

19 See for example, Paul Hemp, The Unraveling of a New England Fish Scam, Boston Sunday Globe A1 (Nov 3, 1991).

Note that it is no defense to price fixing that competition would reduce revenues or drive some firms out of business. The argument that competition is ruinous in that it drives down prices and reduces profits is not legally cognizable. See Socony, 310 US at 221-22.

${ }^{50}$ Suppose that the cost of educating a student is $\$ 5,000$. Suppose further that the highest reservation price-the highest price the most willing student would pay-is $\$ 16,000$. If price discrimination is perfect, the college will set the base tuition at $\$ 16,000$ and charge the most willing student that amount. For students with lower reservation prices the college will provide financial aid to ensure that the actual cost to the student is equal to his reservation price. Thus, a student with a reservation price of $\$ 10,000$ would receive $\$ 6,000$ in aid each year. Under competitive circumstances, however, the base tuition would be equal to cost: $\$ 5,000$. The latter student, despite receiving no financial aid under the competitive regime, is better off by $\$ 5,000$.

${ }^{52}$ See Philip Benoit, Overlap Group Regrouping?, Wash Times D4 (Sep 3, 1991) (effect of competition is to transfer funds from the rich to the talented). 
2. Output effects.

Courts have indicated that the applicability of the per se rule to a trade restriction may depend on whether the restriction reduces output. ${ }^{52}$ Normally, artificially high prices decrease output because higher prices lead to decreased consumer demand for a product. However, members of the financial aid cartel may insist that a high base tuition does not reduce the number of college students. ${ }^{53}$ Individual schools may each independently limit the size of the student body in order to maintain the quality of the education provided, ${ }^{54}$ or because the cost of increased capacity is prohibitively high.

The fact that collusion may not affect output does not make collusion legal, however. If the number of student spaces is actually fixed, then a higher cartel price merely transfers wealth either from one student to another or from one student to the various beneficiaries of university spending. Neither of these transfers is commensurate with the Sherman Act's goal of improving the welfare of consumers as a whole. ${ }^{\mathbf{5}}$ Thus, the ambiguous effect on output should carry little weight in a legal analysis of the education cartel.

\section{Antitrust Treatment of the Education Cartel as an ORDINARY BUSINESS}

Schools make a number of arguments to justify collusion: financial aid fixing is not the same as price-fixing; ${ }^{56}$ students should choose schools on the basis of quality, not price; ${ }^{57}$ competition would diminish educational quality; ${ }^{58}$ the schools can properly as-

'2 See Broadcast Music, 441 US at 19-20 (per se rule is applied when "the practice facially appears to be one that would always or almost always tend to restrict competition and decrease output").

${ }^{83}$ See Note, 94 Harv L Rev at 817 (cited in note 45) (arguing that cross-subsidization increases output of education by increasing the number of students who can afford to go to college). This argument ignores the likelihood that any increase in demand among financial aid recipients who could not otherwise afford to attend college is at least partially offset by a decrease in demand by two other groups of students: (1) students who are forced to pay higher-than-competitive net tuition; and (2) students who, in the absence of the cartel's collusion, would have benefitted from a bidding war for desirable students. When these two groups are taken into account, the proposition that cross-subsidization actually increases output of education is questionable.

s4 Garvin, The Economics of University Behavior at 39 (cited in note 31).

ss See note 89 .

so See Section II.A.

s7 See Section II.B.

ss See Section II.C. 
sert the joint venture defense to Sherman Act violations;; ${ }^{59}$ and collusion equitably redistributes resources from rich students to poor students. These arguments are analagous to arguments which were properly rejected when made outside of the educational context. Once these arguments are rejected in the educational context, the price-fixing conduct of the education cartel is similar to the illegal scheme in American Column \& Lumber Co. $v$ United States. ${ }^{60}$

In American Column \& Lumber Co., a trade association frequently published reports of the sales, purchases, production levels, and inventories of its members. ${ }^{61}$ The trade association required members to report any changes in price immediately. ${ }^{62}$ It also exerted significant pressure on members, at association meetings and through mailings, to curtail output and to raise prices. ${ }^{63}$ The Supreme Court held that these actions violated $\S 1$ of the Sherman Act. ${ }^{64}$ If the allegations raised about the "education cartel" can be proven, the dissemination of financial aid information and the coordination of base and net tuition rates among cartel members should similarly violate the Sherman Act. The following sections contend that the various arguments advanced by the schools should not protect them from Sherman Act liability.

\section{A. "Fixing Financial Aid is Not Equivalent to Fixing Prices"}

Contrary to the schools' assertions, an agreement to fix financial aid awards is functionally equivalent to an agreement to fix prices. The antitrust laws recognize that price-fixing includes the fixing of other terms of trade besides price. In Catalano, Inc. $v$ Target Sales, Inc., ${ }^{65}$ for example, the Supreme Court held that an agreement among beer wholesalers to eliminate the extension of interest-free credit to buyers was qualitatively the same as an agreement to eliminate price discounts, and was therefore an illegal price-fixing agreeement. ${ }^{66}$

A refusal to offer more finaricial aid is analogous to a refusal to extend credit. Like credit terms, financial aid lowers the real price of education. Financial aid awarded by a school to offset tuition reduces the net tuition a student must pay. By agreeing on the

\footnotetext{
59 See Section II.D.

so 257 US 377 (1921).

61 Id at 394-95.

2 Id at 395 .

es Id at 402-09.

64 Id at 411-12.

63446 US 643 (1980) (per curiam).

${ }^{66}$ Id at 648 (applying per se rule).
} 
amount of financial aid, schools are effectively conspiring to change the price the student must pay.

\section{B. "Students Should Choose on the Basis of Quality, Not Price"}

Schools that fix tuition or financial aid may argue that the resulting restriction on consumer choice is actually desirable, as it forces each student to choose a school for educational, rather than financial, reasons ${ }^{67}$ College officials believe it is inappropriate for students to consider price when deciding where to attend college. ${ }^{88}$

This argument is fallacious. A cartel of schools does not prevent its prospective students from considering price. Instead, a cartel merely robs students of the opportunity to consider the richer variety of price-quality combinations that would probably be offered in a competitive market. Indeed, the only price comparisons the cartel insulates against are price comparisons among schools in the cartel. Students still face the decision of whether to purchase a highly-priced cartel education as opposed to a cheaper non-cartel education. To be sure, a student will not consider price when choosing among equally-priced cartel schools, but this outcome is undesirable from the student's perspective if the underlying suspicion of the Sherman Act-that collusion among competitors results in high prices-is right. A student deciding on the basis of quality among three schools charging $\$ 20,000, \$ 20,000$, and $\$ 20,000$, is hardly better off than a student choosing among schools charging $\$ 15,000, \$ 16,000$, and $\$ 17,000$.

Moreover, as with any purchase, students should be able to save money, if they so desire, by attending a lesser quality school. ${ }^{68}$ There is no reason to think that, in deciding what level of educa-

${ }^{67}$ See Gray, NY Times A15 (cited in note 19) (aim is to allow students "to select a school that offers the most suitable education, not the most money"); Financial Aid For The 'Haves', Boston Globe A22 (May 26, 1991) ("[S]tudents admitted to more than one college are encouraged to make their final choice based solely on what each college offers academically rather than on its cost."). But see Note, 94 Harv L Rev at 816 (cited in note 45) (rejecting justification that financial aid-fixing encourages choice on the basis of quality).

${ }^{68}$ Antitrust and Academe, Boston Globe A30 (Aug 27, 1989) ("The aid agreements, reducing if not eliminating money as a consideration, encourage choice on more germane grounds.").

os One might argue that education is different from other goods for several reasons: because the consumers of education are students who are too young to make decisions for themselves, because education is more expensive than other goods, and because education is more important than most other goods. However, merely pointing out the differences between college education and a car, for example, does not explain why college education should be cartelized. Even if high school students may be too young to decide where to go to college, older family members also take part in the decision. The fact that a college education is expensive is also an argument why cartels (which typically increase price) should be 
tional quality a family can afford, a university bureaucrat is a better decisionmaker than the student's family. Admissions and financial aid officers, whose partial function is to sell their schools, may overvalue the importance of educational quality relative to the economic sacrifices of achieving it. Imagine if car dealers increased the sales price of cheap cars relative to the price of expensive cars in order to "protect" consumers from the influence of price and to force them to choose a car on the basis of quality. ${ }^{70}$

Far from embracing the "quality, not price" argument, the Supreme Court rightly frowns on competitors that set an equal price for dissimilar products. ${ }^{71}$ In NCAA $v$ Board of Regents, ${ }^{72}$ the Court condemned an arrangement by colleges that gave the same television fees to losing football teams as winning football teams because a "restraint that has the effect of reducing the importance of consumer preference in setting price and output is not consistent" with the fundamental goal of consumer welfare. ${ }^{73}$ The Court compared the arrangement to the illegal price restraint in Arizona $v$ Maricopa County Medical Society, ${ }^{74}$ which tended to give the "same economic rewards" to all doctors regardless of experience skill, training, or willingness to employ innovative or difficult procedures. ${ }^{75}$

\section{C. "Competition Would Diminish the Quality of Education"}

Schools may argue that charging lower, competitive prices would require them to sacrifice educational quality. However, this argument does not provide a valid antitrust defense. Competitive markets reward firms that produce higher quality products. Highquality firms can either charge a higher price to consumers or take business from low-quality competitors. Therefore, competitive firms will make any cost-justified quality improvements that are desired by consumers. In National Soc. of Professional Engineers $v$ United States, ${ }^{76}$ the Court specifically rejected the defendant's

avoided, not embraced. The importance of college education also cuts both ways: should really important decisions be taken away from families?

${ }^{70}$ See Richmond, $17 \mathrm{~J}$ Coll \& Univ L at 297 (cited in note 22).

72 NCAA, 468 US at 107; Standard Sanitary Mfg. Co. $v$ United States, 226 US 20, 41 (1912); Professional Engineers, 435 US at 684-85.

${ }^{72} 468$ US 85 (1984).

73 Id at 107.

${ }^{74} 457$ US 332 (1982).

75 NCAA, 468 US at $107 \mathrm{n} 33$, citing Maricopa County, 457 US at 348.

${ }^{76} 435$ US 679 (1978). 
contention that competition would decrease the quality of engineering:

The assumption that competition is the best method of allocating resources in a free market recognizes that all elements of a bargain-quality, service, safety, and durability . ..., are favorably affected by the free opportunity to select among alternative offers. ${ }^{77}$

There is no reason why this assumption should not apply to colleges and universities. Competition, not collusion, among elite schools is the antitrust law's preferred means to obtain high quality learning institutions. ${ }^{78}$

\section{The Joint Venture Defense}

Courts have recognized that antitrust law should give special treatment to cooperative ventures that provide higher output by reducing costs. ${ }^{79}$ In Broadcast Music, Inc. $v$ Columbia Broadcasting System, Inc., ${ }^{80}$ the Court held that the rule of reason ${ }^{81}$ governed the activities of a central clearinghouse that purchased, and resold as a package, the rights to musical compositions. ${ }^{82}$ The case did not fall into the per se category because the ability of the central clearinghouses to negotiate for each musician generated a "substantial lowering of costs," if each individual musician were to sell licenses to each customer. ${ }^{84}$ If each composer had to individually license each entity that wanted to play his or her work the transaction costs would be prohibitive. Thus, the blanket license provided by the defendant created a product that would be otherwise unavailable to consumers due to the prohibitive cost of individual licensing. ${ }^{85}$

Similarly, courts have also upheld the joint regulations of the National Collegiate Athletic Association on the rationale that they

\footnotetext{
77 Id at 695.

78 The possibility that quality education is underprovided by the market is discussed in Section III.

79 Broadcast Music, 441 US at 23 ("Joint ventures and other cooperative arrangements are also not usually unlawful, at least not as price-fixing schemes, where the agreement on price is necessary to market the product at all.").

so 441 US 1 (1979).

s2 See notes 13-14 and accompanying text.

82441 US at $24-25$.

${ }^{83}$ Id at 21.

s. Id at 21-22.

ss Id at 20.
} 
were necessary to protect amateurism. ${ }^{86}$ In NCAA $v$ Board of Regents, the Supreme Court recognized that joint amateur regulations of college football are essential to the provision of the product of amateur college football. ${ }^{87}$

Collusive financial aid practices are not, however, essential to providing education. ${ }^{88}$ Unlike Broadcast Music, in which collusion was necessary to offer an affordable package of music licenses, the non-price attractiveness of a school to a consumer is unaffected by the financial aid policies of other schools. Neither marketing nor cost-cutting devices necessitate that Ivy League schools coordinate tuition policies. At best, collusion generates profits that are used to attract a diverse student population through financial aid awards. However, to the extent that consumers demand a diverse student body, an individual school can independently craft financial aid policies to achieve that goal. If consumers demand and can pay for diversity, a college acting unilaterally could itself charge those students higher tuition and use the revenue to provide financial aid to attract diverse students. In summary, since collusion is not a necessary prerequisite for providing educational services, the joint venture defense should not apply.

\section{E. The "Rich-to-Poor" Redistribution Defense}

Because one of the objectives of the Sherman Act is to maximize consumer welfare ${ }^{89}$ the colluding schools might argue that the increase in consumer welfare resulting from the shift of resources from rich to poor students justified the collusion under the Sherman Act. Collusion on financial aid and tuition has an egalitarian appeal in that collusion may facilitate more financial aid to

${ }^{86}$ Hennessey o NCAA, 564 F2d 1136, 1153-54 (5th Cir 1977) (rule limiting each team to two football coaches); Jones $v$ NCAA, 392 F Supp 295, 304 (D Mass 1975) (rule forbidding students who had previously played a sport for pay to compete as amateur athletes in the NCAA). Courts have upheld the NCAA rule restricting compensation of college football players as necessary in order to preserve amateur college football as an alternative to professional football. McCormack $v$ NCAA, 845 F2d 1338, 1344-45 (5th Cir 1988); United States $v$ Walters, 711 F Supp 1435, 1442 (N D Ill 1989).

87 468 US at 101-02. The Court nonetheless ruled against the defendants on the ground that restricting the televising of college football was not essential to the provision of amateur football. Id at 117-20.

${ }^{88}$ Richmond, $17 \mathrm{~J}$ Coll \& Univ L at 296 (cited in note 22).

89 Phillip Areeda and Donald F. Turner, Antitrust Law IT 103-13 at 7-33 (Little, Brown, 1978); Robert H. Bork, The Antitrust Paradox: A Policy at War with Itself 50-89 (Basic Books, 1978); Robert H. Bork, Legislative Intent and the Policy of the Sherman Act, 9 J Law \& Econ 7 (1966). 
poor students than would occur under a competitive system. ${ }^{90} \mathrm{Col}-$ lusion also may have a utilitarian appeal in that, assuming a poor student values money more than a rich student, the cartel increases social welfare by shifting resources from rich to poor students. ${ }^{91}$

This redistribution argument is flawed for four reasons. First, the antitrust law has not traditionally attempted to increase consumer welfare by transferring welfare from one group of consumers to another group. Thus, transferring money from rich students to poor students falls outside the traditional scope of the antitrust law's consumer welfare goal. Second, the general argument that the benefit to some students outweighs the harm to others is really a more sophisticated version of the discredited "reasonable price" argument. Such a defense would be the equivalent of saying that the aggregate price charged to the entire market is reasonable. Yet, the Supreme Court has expressly established that it is no defense that an antitrust defendant fixes price at a reasonable level. ${ }^{92}$ Similarly, it should not be a defense that a cartel charges one student $\$ 40$ more than the competitive price and another student $\$ 40$ less. ${ }^{93}$ Third, whatever the merits of social and economic equality in the education context, the redistribution argument is dubious because it is empirically difficult to make value comparisons between various individuals. ${ }^{94}$ Fourth, inter-consumer redistribution is akin to arguments, rejected by the Supreme Court in other contexts, that cartel profits are used responsibly. ${ }^{95}$

With the exception of the public goods issue examined below in Section III, the arguments that have been (or could have been) made on behalf of the schools have been rejected when argued by ordinary businesses. So far as these arguments are concerned, the higher education cartel should be held liable for horizontal pricefixing.

\footnotetext{
${ }^{80}$ See Anthony B. Atkinson and Joseph E. Stiglitz, Lectures on Public Economics 486 (McGraw-Hill, 1980) ("[D]istributional reasons are probably the primary rationale for the public provision of education-either because it reduces inequality of endowments, or because access to at least a minimum level of education is an objective in itself.").

91 But see Richard A. Posner, Economic Analysis of Law 434 (Little, Brown, 3d ed 1986) (noting difficulties with the argument that redistributing wealth from rich to poor increases social welfare).

${ }^{82}$ See Trenton Potteries, 273 US at 398; Socony, 310 US at 221.

${ }^{23}$ A more powerful version of the redistribution argument is that transfers of financial aid from richer students to poorer students improves economic efficiency by solving a market failure. This argument is treated in Section III.

24 See Posner, Economic Analysis of Law at 434-35 (cited in note 91).

${ }^{95}$ See Section III.A.
} 


\section{Schools, the Public Goods Problem, and the Sherman ACT}

This section examines the possibility that collusion among schools achieves a desirable result which could not be achieved by a competitive system. ${ }^{96} \mathrm{I}$ argue that although such a possibility exists, a competitive system that includes charitable contributions and bidding for diverse students would produce some social benefits. ${ }^{97}$ Furthermore, a competitive system would avoid the social loss due to cartel pricing. More importantly, the philosophy underlying the Sherman Act expresses a belief that competition is the best way to allocate resources. The courts are therefore correct in rejecting social justifications for cartels, ${ }^{98}$ and should similarly reject such justifications for the education cartel.

A. Present Legal Treatment of Social Benefits Under Antitrust Law

Courts are increasingly reluctant to consider social justifications for restrictive trade practices, especially those that depend upon the defendant's good faith in disposing of its monopoly profits in a socially beneficial manner. Although the Supreme Court has suggested, in dicta, that courts applying the Sherman Act should treat the professions "differently" than other businesses because the professions provide social benefits, ${ }^{99}$ the Court has never put this dictum into practice. ${ }^{100}$ Trade restrictions that protect consumer safety, however, have been upheld where they directly create a public benefit and do not rely on a cartel's good faith to channel profits into a socially beneficial project. ${ }^{101}$

${ }^{96}$ See Section III.B.

${ }^{\theta 7}$ See Section III.B.1.

${ }^{8 B}$ See Section IV.

${ }^{9}$ Goldfarb v Virginia State Bar, 421 US 773, 788 n 17 (1975) (noting the "public service aspect" of the professions). See also Boddicker v Arizona State Dental Association, 549 F2d 626, 632 (9th Cir 1977) (noting that the professions exist to "serve the public"). See also Phillip Areeda, Antitrust Analysis: Problems, Text, Cases, 39-40, 194-96 (Little, Brown, 3d ed 1981) ("[T] here might be specific instances in which the claim of social virtue may redeem anticompetitive acts or at least mitigate the application of antitrust laws.").

100 See Goldfarb, 421 US at 791-92 (condemning a minimum fee schedule for lawyers published by a state bar association); Professional Engineers, 435 US at 692; FTC $v$ Superior Court Trial Lawyers Ass'n, 110 S Ct 768, 775 (1990); United States v Women's Sportswear Manufacturers Association, 336 US 460, 464 (1949).

${ }^{101}$ See Tripoli Co. $v$ Wella Corporation, 425 F2d 932, 938 (3d Cir 1970) (restriction on the resale of "potentially dangerous products" does not violate the Sherman Act). 
1. Social benefits of an otherwise illegal trade restriction.

The Supreme Court is reluctant to view the public benefits provided by a private cartel as an antitrust defense. In Professional Engineers, the Court rejected the defendant's asserted defense that a ban on competitive bidding by engineers protected public safety by shielding engineers from competitive pressures that might cause the engineers to do inferior work. ${ }^{102}$ The Court did not decide whether the bidding ban affected safety but said that the "judiciary cannot indirectly protect the public against this harm by conferring monopoly privileges on the manufacturers."103 Professional Engineers can be justified in two ways. First, at best the restraint was indirectly, rather than directly, related to safety. Second, safety is a poor justification for noncompetitive behavior because safety, like any other element of product quality, is provided by the competitive market. ${ }^{104}$ In Professional Engineers, the Court favorably noted Tripoli Co. $v$ Wella Corp. ${ }^{105}$ in which the Third Circuit upheld a hair conditioner manufacturer's requirement that its hair conditioners be sold only to professional retailers because the requirement's purpose was to protect safety and limit product liability. ${ }^{106}$ In Tripoli, unlike Professional Engineers, the restraint directly related to product safety.

In FTC $v$ Superior Court Trial Lawyers Ass' $n,{ }^{107}$ a group of lawyers paid by the District of Columbia to represent indigent defendants organized a boycott to protest their low fees. ${ }^{108}$ The Supreme Court held that the lawyers' refusal to work was an unfair trade practice under $\S 5(\mathrm{a})(1)$ of the Federal Trade Commission Act. ${ }^{109}$ The Court assumed for the purposes of its discussion that better legal representation for the indigent was worthwhile and that extra fees for lawyers improved their representation of public

102435 US at 693-96.

103 Id at 695-96.

104 Of course, the market may not always provide a socially optimal amount of product safety because of information problems-the information needed might be too complex, or it might be too costly to gather the information. Nevertheless, product safety rules and product liability tort litigation, rather than antitrust laws, address these market failures. Posner, Economic Analysis of Law at 153, 351 (cited in note 91).

${ }^{105}$ Professional Engineers, 435 US at 696 n 22, citing Tripoli, 425 F2d 932 ("Courts have ... upheld marketing restraints related to the safety of a product, provided that they have no anticompetitive effect and that they are reasonably ancillary to the seller's main purpose of protecting the public from harm or itself from product liability.").

${ }_{108}$ Tripoli, 425 F2d at 936-39.

$107110 \mathrm{~S}$ Ct 768.

108 Id at 771-72.

${ }^{109}$ Id at 774. See 15 USC $\S 45(a)(1)$ (1988). 
interest clients, presumably by enabling them to reduce their work load. ${ }^{110}$ Nevertheless, the Court did not consider its task to "pass upon the social utility or political wisdom of price-fixing agreements." 11 The Court refused to consider "social justifications" for a restraint of trade because the statutory policy underlying the Sherman Act presumes that competition is beneficial. ${ }^{112}$

\section{Institutional considerations.}

Just as it is no defense that a trade restriction indirectly provides a social benefit, it is no defense that an institution typically invests its cartel income in socially beneficial enterprises or that it voluntarily refrains from using its cartel power altogether. Self-regulatory considerations-such as whether the organization is nonprofit, whether a learned profession is involved, or whether there is a mixed commercial/non-commercial status-do not confer an antitrust exemption on a cartel.

Non-profit organizations do not enjoy a judicial exemption from the Sherman Act. The Court in NCAA observed that:

There is no doubt that the sweeping language of $\S 1$ applies to non-profit entities, and in the past we have imposed antitrust liability on nonprofit entities which have engaged in anticompetitive conduct. ${ }^{113}$

Although some commentators and the Supreme Court in dicta have indicated that there might be an antitrust exemption for learned professions, ${ }^{114}$ recent Supreme Court cases have nonetheless held members of learned professions liable for antitrust violations. In Goldfarb $v$ Virginia State Bar, ${ }^{115}$ the Supreme Court held that a state bar association violated the Sherman Act by adopting a minimum fee schedule for lawyers. Although the Court indicated

110 Trial Lawyers, $110 \mathrm{~S} \mathrm{Ct}$ at 774.

111 Id.

112 Id at 775 .

${ }^{13}$ NCAA, 468 US at $100 \mathrm{n} 22$ (citations omitted). See also American Society of Mechanical Engineers, Inc. $v$ Hydrolevel Corp., 456 US 556, 576 (1982) (nonprofit trade association held liable for an antitrust violation).

114 The Atlantic Cleaners \& Dyers, Inc. v United States, 286 US 427, 436-37 (1932) (concluding that "[w] herever any occupation, employment, or business is carried on for the purpose of profit, or gain, or a livelihood, not in the liberal arts or in the learned professions, it is constantly called a trade" (emphasis in original) and is subject to the Sherman Act); United States $v$ National Association of Real Estate Boards, 339 US 485, 491-92 (1950) (subjecting real estate brokers to requirements of Sherman Act, but declining to "intimate an opinion on the correctness of the application of the term to the professions").

115 421 US 773 (1975). 
that professions, especially those that serve a public interest, should be held to a different standard of conduct under the Sherman Act, ${ }^{116}$ the Court nonetheless held the Virginia State Bar Association liable for an antitrust violation. ${ }^{117}$ Similarly, in Professional Engineers, the Court held an engineering association liable despite its status as a learned profession, ${ }^{118}$ and in Maricopa County Medical Society, ${ }^{119}$ the Court condemned a fee ceiling by an association of doctors. These cases demonstrate that there is no blanket "learned profession" exception to antitrust liability. ${ }^{120} \mathrm{De}-$ spite the broad applicability of antitrust laws, the colluding schools might argue that these laws do not apply to the noncommercial aspects of the liberal arts and learned professions. ${ }^{121}$ However, college financial aid policies are commercial for the purposes of the Sherman Act. Educational services compete for other goods in the consumer's basket. ${ }^{122}$ Consumers of education presumably shop around for the best college and derive utility from college education, including future income. If the goal of the Sherman Act is to increase consumer welfare, the Sherman Act should protect consumers of education.

118 In Goldfarb, the Court said:

The fact that a restraint operates upon a profession as distinguished from a business is, of course, relevant in determining whether that particular restraint violates the Sherman Act. It would be unrealistic to view the practice of professions as interchangeable with other business activities, and automatically to apply to the professions antitrust concepts which originated in other areas.

421 US at $788 \mathrm{n} 17$.

217 Id at 793.

118435 US at 696.

119457 US at $332,356-57$.

${ }^{220}$ For a summary of cases discussing the "learned profession" exemption from the Sherman Act, see Annotation, "Learned Profession" Exemption in Federal Antitrust Laws, 39 ALR Fed 774 (1978).

121 Klor's, Inc. v Broadway-Hale Stores, Inc., 359 US 207, 213 n 7 (1959) (the Sherman Act "is aimed primarily at combinations having commercial objectives and is applied only to a very limited extent to organizations ... which normally have other objectives"); Marjorie Webster Junior College, Inc. $v$ Middle States Ass'n of Colleges \& Secondary Schools, Inc., 432 F2d 650, 654 (DC Cir 1970) ("[T]he proscriptions of the Sherman Act were 'tailored ... for the business world,' not for the noncommercial aspects of the liberal arts and the learned professions. In these contexts, an incidental restraint of trade, absent an intent or purpose to affect the commercial aspects of the profession, is not sufficient to warrant application of the antitrust laws.") (citations omitted).

122 Garvin, The Economics of University Behavior at 160 (cited in note 31), argues: [U]niversities are fundamentally economic organizations. ... [Universities] regularly assess their competition, analyze trends in demand, engage in advertising and other forms of product differentiation and decide how their institution's limited resources can best be spent meeting the organization's goals. 


\section{B. Identifying the Market Failure}

Although courts do not take into account the social benefits of an otherwise illegal trade practice, some commentators have argued that a cartel may be justified if it solves a problem that the market cannot solve. ${ }^{123}$ One such problem is the "public good." This subsection explores whether schools may properly argue for an exemption from the Sherman Act because they provide public goods.

Under ideal circumstances, a perfectly functioning market would provide the efficient ${ }^{124}$ quantity and price of a good. ${ }^{126}$ Yet a public good has two characteristics different from other goods: it is both nonrival and nonexclusive. ${ }^{128} \mathrm{~A}$ good is nonrival if it costs nothing to provide it to an extra consumer; it is nonexclusive if the producer cannot control who gets it. ${ }^{127}$ For example, national defense is nonrival since new citizens arriving in the country are protected at no extra cost. It is nonexclusive because beneficiaries of the protection cannot easily exclude others from enjoying the good. Thus, national defense is a public good. On the other hand, a shirt is not a public good. A shirt is rival because it costs more to provide shirts to two people than to one. A shirt is exclusive because only one person can wear a shirt at a time.

One of the most important market failures is that the market underprovides public goods. The market is inefficient in this way because the private cost of the good outweighs the private benefit of the good even though the total social benefit outweighs the cost of the good. ${ }^{128}$ Since the consumer does not take into account the external benefits of the good, the consumer is willing to pay only for the private benefit that he receives from the good. As a result, some goods whose total benefits outweigh their costs will not be produced. For example, assume a unit of national defense costs $\$ 10$. Assume that the benefit that accrues to one person is $\$ 5$ and the benefit accruing to the rest of society is $\$ 15$. The person weighing a benefit of $\$ 5$ against a cost of $\$ 10$, will not purchase national

${ }^{123}$ See Note, 94 Harv L Rev at 812 (cited in note 45); Note, Tackling Intercollegiate Athletics: An Antitrust Analysis, 87 Yale L J 665, 673 (1978).

124 "Optimal" is defined as the quantity (and corresponding price) at which the social cost of producing one more unit of a good exceeds the social benefit of that unit. See David Friedman, Price Theory 455, 458 (South-Western, 2d ed 1990).

${ }^{125}$ Pindyck and Rubinfeld, Microeconomics at 297 (cited in note 39).

${ }^{128}$ Id at 638.

${ }^{127}$ Id.

${ }^{128}$ See Friedman, Price Theory at 513 (cited in note 124). 
defense even though the total social benefit, $\$ 20$, outweighs the cost of $\$ 10$.

One possible solution to the underprovision of a public good is government production of the good, as is the case with national defense. ${ }^{129}$ Alternatively, Congress or the courts could choose to legalize a cartel, thus enabling the cartel to use its cartel profits to produce the public good. ${ }^{130}$ Nevertheless, provision of a public good by the government imposes costs in the form of taxes; provision of a public good by a cartel imposes costs in the form of higher prices.

If colleges try to justify their cartel by arguing that it produces a public good, ${ }^{131}$ the question becomes "what public good is produced?" One can isolate the benefits of education to determine if a competitive market is likely to provide those benefits. Three different groups may benefit from the education enabled by financial aid: the student, the school, and society. Only if one or more of these groups acquire benefits which have public good aspects can there be any justification for deviating from the outcome created by the competitive market.

1. Private benefits to students and colleges.

If the market operates properly, any private benefits of higher education, such as improvements in self-worth, employability or social status, are incorporated into the student's private decision in choosing the amount and quality of education. ${ }^{132}$ Imagine if higher education were stripped of all other benefits except those that accrued to the student. The modified product would not be a public good. Because it would be rival (it costs more to educate additional students) and exclusive (schools can limit enrollment), the amount and quality of education, for the purposes of private benefit, would be optimal.

The only exception to this is if, due to their inability to borrow against future earnings, students are unable to finance educa-

\footnotetext{
129 Pindyck and Rubinfeld, Microeconomics at 638 (cited in note 39).

${ }^{130}$ This is basically the standpoint of the student scholarship cited earlier. See note 123.

${ }^{131}$ A common justification for collusion among schools, that collusion is necessary to provide funds for needy students, implies that the competitive market would underprovide education to certain students. For an example of this argument, see Financial Aid For the 'Haves', Boston Globe A22 (cited in note 67).

${ }^{132}$ Michael A. Crew and Alistair Young, Paying by Degrees 16-17 (Institute of Economic Affairs, 1977) (private education is efficient only if market is free of cartels and all benefits of education are appropriated by the student).
} 
tion even though the benefits of the education might outweigh the costs. ${ }^{133}$ Nevertheless, this exception would be better handled through government loan programs than by antitrust exemptions. Although the cartel may provide financing for students who cannot afford education, it raises the money by increasing the price of education to other students. Thus, it will deter some students from attending the colleges participating in the cartels.

Enrolling outstanding or diverse students confers additional benefits on both fellow students and the college. ${ }^{134}$ If higher education were stripped of all private or public benefits except this one, that product would not be a public good. Such a product would be rival and exclusive in that only students attending the college and the college itself receive the benefit. Since the benefits of diversity to other students has no public goods aspect, one would expect the market to perform efficiently along this dimension. Free competition among schools would correctly account for this benefit because, to the extent that diversity enhances educational quality, schools with diverse student bodies will be able to charge higher tuition. If tuition were allowed to differ from school to school on the basis of quality, the universities which spent money on quality would be compensated by increased tuition rates fueled by increased consumer demand. Cartel power is unnecessary to produce the private benefit of diversity.

${ }^{133}$ Commentators have noted that the private benefits of education may be underprovided by the market, due to the limited ability of students to borrow against future earnings. Marc Nerlove, On Tuition and the Cost of Higher Education: Prologomena to a Conceptual Framework, $80 \mathrm{~J}$ Pol Econ S178, S185 (1972). A student has an economic incentive to borrow money for education and pay the loan back after he or she has reaped the gains from his or her increased "human capital." See generally Gary S. Becker, Human Capital 195 (National Bureau of Economic Research, 1975); Theodore Schultz, Capital Formation by Education, $68 \mathrm{~J}$ Pol Econ 571 (1960); Lester C. Thurow, Investment in Human Capital 77-79 (Wadsworth, 1970). However, private student loans, though substantial, are underprovided because the student cannot legally guarantee that he or she will pay the loan back. Reasons for this include: (1) the incapacity of minors to enter into contracts, (2) the inability of the courts to force someone to work to pay off his or her debts, (3) the students' lack of loan collateral, and (4) the fact that some parents are unwilling to co-sign a loan. Thus a bank may be unwilling to make an efficient loan for fear of not collecting. See Mark Blaug, An Introduction to the Economics of Education 4-5 (Penguin, 1970).

134 A Harvard College catalog, cited in Regents of Univ. of California v Bakke, 438 US 265, 316 (1978), stated: "A farm boy from Idaho can bring something to Harvard College that a Bostonian cannot offer. Similarly, a black student can usually bring something that a white person cannot offer." 
2. Public benefits of elite higher education.

Although many of the benefits of higher education accrue to parties who can be charged for those benefits, education is often considered to be a public good ${ }^{136}$ because some of the benefits of education (heightened political participation, crime reduction, ${ }^{136}$ increased productivity, ${ }^{137}$ and increased knowledge) are social and not private. ${ }^{138}$ Thus, the argument goes, there are two reasons why education is underprovided by the competitive market. First, education is a public good. Second, students may not be able to pay for profitable education. ${ }^{139}$ For these reasons and others, state and federal governments finance elementary, secondary, and higher education, and the federal government provides need-based financial aid to college students and graduate students.

The colluding schools might argue that these reasons-market failure and inability to pay for profitable education-also justify an education cartel, provided it is run properly. By using higher-thancompetitive net tuition to generate financial aid to poor students, the cartel helps to provide more education by giving poor students (who would otherwise go uneducated) enough financial aid to go to school. ${ }^{140}$

There are at least two problems with this argument. First, it is not clear that the cartel increases the total output of elite education. ${ }^{141}$ Second, the additional gains in social benefit provided by elite higher education, as compared to either non-elite higher education or to secondary education only, are probably relatively small. Society can obtain most of the social benefits achievable through education by providing secondary education, or, better yet, non-elite higher education. Even if college education increases political awareness and decreases propensity to commit crime, it seems unlikely that education at an elite private school provides

${ }^{135}$ Blaug, An Introduction to the Economics of Education at 107 (cited in note 133) (education as a quasi-public good).

${ }^{136}$ See Isaac Ehrlich, On the Relation Between Education and Crime, in F. Thomas Juster, ed, Education, Income and Human Behavior 313, 334 (McGraw-Hill, 1975).

${ }^{137}$ See Becker, Human Capital at 194-95 (cited in note 133).

${ }^{138}$ See Elchanan Cohn, The Economics of Education 34-35 (Ballinger, rev'd ed 1979).

${ }^{130}$ See note 133.

${ }^{140}$ To illustrate this point, imagine there are only two students in the market for college education, a rich student and a poor student, and that only the rich student can afford to pay the price of education. With cartel power, the school could force the rich student to pay a higher tuition (but not so much as to dissuade the rich student from going to school) and use the tuition to encourage the poor student to attend school as well. Society would then receive the social benefit of two college-educated citizens instead of one.

${ }^{141}$ See Section I.D.2. 
these social benefits to a greater extent than education at a public school.

\section{Proposed Treatment of The Higher Education Cartel}

A. Why the Sherman Act Should Apply to Schools That Fix Financial Aid and Tuition

Supreme Court precedent dictates that the Sherman Act should apply to the school cartel. In Trial Lawyers, ${ }^{142}$ the lawyers attempted to justify their boycott-induced fee increase by arguing that higher fees would improve legal representation for the indigent. ${ }^{143}$ Because the Supreme Court rejected the trial lawyers' public welfare defense on the ground that indirect social benefits do not justify restraints of trade, ${ }^{144}$ courts similarly should reject the argument that price-fixing by universities leads to social benefits.

Second, the Sherman Act should apply because such an outcome best reflects congressional intent. Had Congress wanted to exempt colleges and universities from the Sherman Act, it could have done so explicitly. Notably, Congress has granted exemptions to numerous other industries. ${ }^{145}$ In fact, Congress explicitly exempted nonprofit schools from the Robinson-Patman Act's prohibition on price discrimination in the purchase of supplies. ${ }^{146}$ Especially after $N C A A,{ }^{147}$ the notion that Congress intended the Sherman Act to apply to universities seems clear.

The third reason why the Sherman Act should apply to the school cartel is that colleges and universities are just as likely to harm consumers as are ordinary businesses. No good reason exists to think that colleges and universities, as non-profit organizations, can be trusted to exercise monopoly power responsibly. One would expect that non-profit institutions are as prone to restraining com-

$142110 \mathrm{~S} \mathrm{Ct} 768$.

143 Id at 773 .

144 Id at 775 .

${ }^{145}$ Section 6 of the Clayton Act, 15 USC $\S 17$ (1988) (labor, agricultural, or horticultural organizations); Webb-Pomerene Act, 15 USC $\$ 62$ (1988) (associations engaged in export trade); Defense Production Act of 1950, 50 USC $\$ 2158$ (1988) (associations entered into with the approval of the President to help provide for the defense of the United States); Small Business Act, 15 USC $\$ 638$ (d)(2) (1988) (agreements between small-business firms providing for a joint program of research and development); Fisheries Cooperative Marketing Act, 15 USC $\S 521$ (1988) (associations of persons engaged in the fishing industry).

${ }^{148} 15$ USC \& 13 (1988). The Act does not apply to supplies purchased for their own use by "schools, colleges, universities, public libraries, churches, hospitals and charitable institutions not operated for profit."

${ }^{147} 468$ US 85. 
petition as for-profit institutions because, as Judge Posner of the Seventh Circuit has noted, "most people do not like to compete" and will seek agreements to avoid competition. ${ }^{148}$ Even if "the managers of nonprofit enterprises are less likely to strain after that last penny of profit [and] be less prone to engage in profit-maximizing collusion[,] by the same token [they may be] less prone to engage in profit-maximizing competition."148 Likewise, in NCAA, the Court questioned the "economic significance of the NCAA's nonprofit character." "150 The Court found no reason why the NCAA was "less likely to restrict output in order to raise revenues above those that could be realized in a competitive market than would be a for-profit entity." 151 It appears, then, that courts have been as dubious of the motives of nonprofit organizations as they have been about for-profit monopolists. As one district court claimed, monopolies are "inherently dangerous" because they cannot be trusted either to refrain from using their market power or to use their power for the public good, "no matter how beneficently they appear to have acted."152 Monopoly power can always be abused because there is "no automatic check and balance from equal forces in the industrial market."153

\section{B. How Competition Among Schools Should Work}

Many of the claimed benefits of the education cartel can be achieved without the cartel's price-fixing conduct. Colleges might be able to collect information on student need from a central collection agency. The universities undoubtedly reap some cost savings from pooling information, such as the ability to easily verify the accuracy of student reports. Because the exchange of information may reduce administrative costs, the joint venture defense described in Broadcast Music ${ }^{154}$ and $N C A A,{ }^{165}$ which protects collusive arrangements that have procompetitive justifications, may

148 United States $v$ Rockford Memorial Corp., 898 F2d 1278, 1285 (7th Cir 1990) (affirming decision of district court to enjoin a merger between two nonprofit hospitals), cert denied, 111 S Ct 295 (1990).

140 Id, citing Hospital Corp. of America v FTC, 807 F2d 1381, 1390-91 (7th Cir 1986).

1 so 468 US at $100 \mathrm{n} 22$

131 Id at $101 \mathrm{n} 22$.

182 United States v United States Shoe Machinery Corp., 110 F Supp 295, 347 (D Mass 1953).

153 Id.

154441 US at $18-23$.

1ss 468 US at $100-04$. 
protect the exchange of financial aid information from antitrust scrutiny.

In order to avoid liability, however, schools should remove elements of their agreement that constitute pressure to fix financial aid or to standardize tuition rates. ${ }^{156}$ Schools should not agree to use the same formula for determining financial aid awards from student resources, ${ }^{157}$ and should not discuss financial aid awards or tuition increases until after those financial aid awards or tuition increases are independently determined by each college. Exchange of final financial aid awards and tuition information after the awards have been made and the applicants have been accepted is legal ${ }^{158}$ unless accompanied by efforts to fix future financial aid awards and tuition. ${ }^{159}$

Legally, colleges can unilaterally offer charitable financial aid using funds donated by alumni or even tuition from other students. Noncartelized colleges and universities would still benefit from tax-exempt status and contributions would still be deductible. Thus, the charitable efforts of colleges would not be eliminated by antitrust liability.

\section{CoNCLUSION}

The fixing of financial aid by elite colleges and universities has no substantial competitive or social justification. Collusion over fi-

\footnotetext{
${ }^{158}$ Exchanges of information that represent the concerted efforts of producers to reduce output or increase prices are illegal. Eastern States Retail Lumber Association v United States, 234 US 600, 614 (1914); American Column \& Lumber Co. $v$ United States, 257 US 377, 411-12 (1921); United States v American Linseed Oil Company, 262 US 371, 390 (1923). See generally Phillip E. Areeda, 6 Antitrust Law $\S 1406$ b (Little, Brown, 1986).

${ }^{157}$ "A number of firms in an industry expressly agreeing to set prices according to a predetermined formula presumably would constitute a violation of Section 1 of the Sherman Act." William R. Andersen and C. Paul Rogers III, Antitrust Law: Policy and Practice 395 (Matthew Bender, 1985).

${ }^{188}$ A mere exchange of price information among competitors is legal. Cement Manufacturers Protective Ass'n v United States, 268 US 588, 603-04 (1925); United States v Citizens \& Southern National Bank, 422 US 86, 113 (1975); Maple Flooring Manufacturers Ass'n $v$ United States, 268 US 563, 582-83 (1925).

${ }^{189}$ In highly concentrated industries, exchange of price information is more suspect, and exchange of information may be the basis for inferring an agreement to set prices even without proof of an effort to set prices. Container Corp, 393 US at 337. Highly concentrated industries tend to be susceptible to the phenomenon of interdependence, or price leadership, where one firm sets a price and its competitors follow suit. Sullivan and Hovenkamp, Antitrust Law, Policy and Procedure at 256 (cited in note 4). Thus, in concentrated industries amenable to price leadership, the sharing of price data may be a "conspiracy, contract, or combination" outlawed by the Sherman Act. Elite schools, which may draw from substantially the same applicant pool, probably possess market power and are also susceptible to price leadership.
} 
nancial aid provides no competitive advantage that schools could not obtain independently. Financial aid that is used to attract quality students has a competitive basis and would occur in a competitive environment. The remainder of financial aid awarded, that given out of altruism, may contribute to public goods such as education and racial harmony. Yet altruistic financial aid may depend upon the cartel profits that schools earn from higher-than-competitive net tuition, and the altruistic use of monopoly profits is not the type of procompetitive defense envisioned by antitrust laws. Lastly, although antitrust laws may not apply to actions taken solely in pursuit of educational goals, restraining competition for students is fundamentally within the economic sphere. A university should not be exempt from antitrust laws merely because it may use its monopoly profits charitably. 


\section{.}

